\title{
Oropharyngeal Cancer pN3 TNM Finding v6
}

National Cancer Institute

\section{Source}

National Cancer Institute. Oropharyngeal Cancer pN3 TNM Finding v6. NCI Thesaurus. Code C64613.

Oropharyngeal cancer with metastasis to one or more lymph nodes, more than $6 \mathrm{~cm}$ in greatest dimension. (from AJCC 6th Ed.) 